PACS: 81.20.Fw

\title{
Synthesis of highly doped Nd:YAG powder by SOL-GEL method
}

\author{
Jahangir Hasani Barbaran, Morteza Farmahini Farahani, Fereshteh Hajiesmaeilbaigi \\ Solid State Lasers Div. Laser Research Center, Tehran, P.O.Box 14155-1339, Iran \\ Phone/fax:8008592 \\ E-mail: jhasani2000@yahoo.com,morteza_farmahini@yahoo.com,fbaibi2000@yahoo.com.
}

\begin{abstract}
The sol-gel method was used for synthesizing Nd:YAG powder. The process contains several steps, for example solving in acid, mixing, evaporation etc. The XRD analysis of prepared powder by sol-gel method showed that the YAG single phase is resulted by heat treatment at $900^{\circ} \mathrm{C}$ for $2 \mathrm{hr}$. By SEM the homogeneity of $\mathrm{Nd}$ distribution in the YAG lattice was observed.
\end{abstract}

Keywords: laser ceramics, Nd:YAG, sol-gel synthesis.

Manuscript received 14.12.04; accepted for publication 18.05.05.

\section{Introduction}

$\mathrm{Nd}$ :YAG $\left(\mathrm{Nd}\right.$ doped $\left.\mathrm{Y}_{3} \mathrm{Al}_{5} \mathrm{O}_{12}\right)$ single crystals are widely used in solid state lasers. The method of growing these single crystals requires long process time and high level of experience and has limitation of crystal size. Therefore recently preparation of transparent ceramic $\mathrm{Nd}$ :YAG has been propounded. In this work sol-gel method was used for synthesizing Nd: YAG powder which can be sintered to transparent ceramic Nd:YAG for laser application [1-4].

Compared with YAG single crystal, transparent ceramic laser materials have the following advantages [5]: 1) easy of fabrication; 2) less expensive; 3) fabrication of large size and high concentration; 4) multilayer and multifunctional ceramic structure; 5) mass production 6) several dopants available: $\mathrm{Nd}^{3+}, \mathrm{Er}^{3+}, \mathrm{Yb}^{3+}, \mathrm{Cr}^{4+}, \mathrm{Tm}^{3+}$, etc.

Previously, Akin, et al. [6] prepared YAG powder by Self-Propagating Combustion Synthesis, then Chung et al. [7] used citrate gel method for synthesis of YAG powder. Also Edita Graskite et al. [8] reported that the single-phase $\mathrm{Ln}$ :YAG $(\mathrm{Ln}=\mathrm{Ce}, \mathrm{Nd}, \mathrm{Ho}, \mathrm{Er})$ is formed after heating of resulted powder by sol-gel method at $1000{ }^{\circ} \mathrm{C}$. In the present study, single phase of $\mathrm{Nd}$ :YAG powder with 4 at $\% \mathrm{Nd}$ concentration was synthesized by sol-gel method at $900{ }^{\circ} \mathrm{C}$.

\section{Experimental procedure}

High pure $\mathrm{Nd}_{2} \mathrm{O}_{3}, \mathrm{Y}_{2} \mathrm{O}_{3}$ and $\mathrm{Al}\left(\mathrm{NO}_{3}\right)_{3} .9 \mathrm{H}_{2} \mathrm{O}$ were used with stoichiometric amounts as the starting materials. The 4 at $\% \mathrm{Nd}$ concentration of $\mathrm{Nd}: \mathrm{YAG}$ was selected. First 27.0855 gr $\mathrm{Y}_{2} \mathrm{O}_{3}$ was dissolved in acetic acid at 70$80{ }^{\circ} \mathrm{C}$, then $1.6817 \mathrm{gr} \mathrm{Nd}_{2} \mathrm{O}_{3}$ was dissolved in acetic acid and added to the previous solution. Also $156.239 \mathrm{gr}$ Aluminum nitrate dissolved in distilled water was added.
The resulting mixture was stirred for 3 hours at about $65{ }^{\circ} \mathrm{C}$. After that 1,2-ethanediol was added to the above solution and stirred for $3 \mathrm{hr}$ at $65^{\circ} \mathrm{C}$. Then it was evaporated while stirring at $65^{\circ} \mathrm{C}$ and finally the transparent gel was obtained. This gel was dried at $110^{\circ} \mathrm{C}$, then grounded and preheated at $800^{\circ} \mathrm{C}$ for $2 \mathrm{hr}$ in an air atmosphere, the white powder was produced. The resulted powder after grinding again, was heated at $900{ }^{\circ} \mathrm{C}$ for $2 \mathrm{hr}$ in an air atmosphere.

The present phases in the heat treated powder were examined by powder XRD with $\mathrm{CuK}_{\alpha}$ radiation (3003 pts, SEIFERT). The Study of the microstructure and morphology of the powder were performed by EDXS analysis and SEM (Model XL30, Phillips, Holland).

\section{Results and discussion}

The XRD pattern of the heated powder to $900{ }^{\circ} \mathrm{C}$ for $2 \mathrm{hr}$ and cooled to room temperature are shown in Fig. 1. This figure exhibit only the YAG phase, and it is in a good agreement with the reference of $\mathrm{Y}_{3} \mathrm{Al}_{5} \mathrm{O}_{12}$ (card $\mathrm{N}$ 33-40). Therefore $900{ }^{\circ} \mathrm{C}$ is enough temperature to resulting $\mathrm{Nd}$ :YAG single phase.

Also Fig. 2 shows Graskite experience that indicate the XRD pattern of an Er:YAG sample synthesized at $1100{ }^{\circ} \mathrm{C}$. The prepared powder investigated by EDAX and SEM. The distribution of $\mathrm{Nd}$ over the entire measured area of the YAG phase is shown in Fig. 3. The bright points in this figure are $\mathrm{Nd}$. This micrograph exhibits very homogeneous distribution of $\mathrm{Nd}$ in the structure.

The morphology of the heat treated powder at $900{ }^{\circ} \mathrm{C}$ for $2 \mathrm{hr}$, is shown in Fig. 4. In this figure necks formed between particles indicate that bondings between them have been started and therefore agglomeration is observed in some places. 


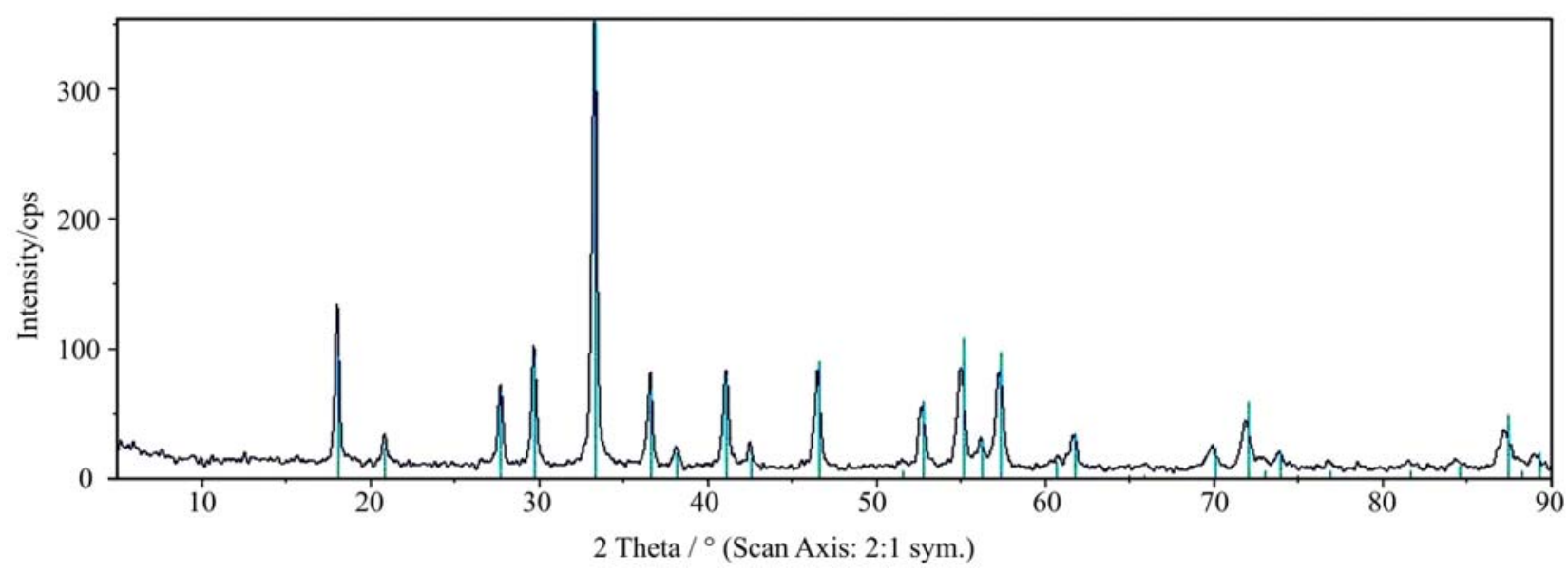

Fig. 1. XRD pattern of the powder (prepared by sol-gel method) heated at $900{ }^{\circ} \mathrm{C}$ for $2 \mathrm{hr}$.

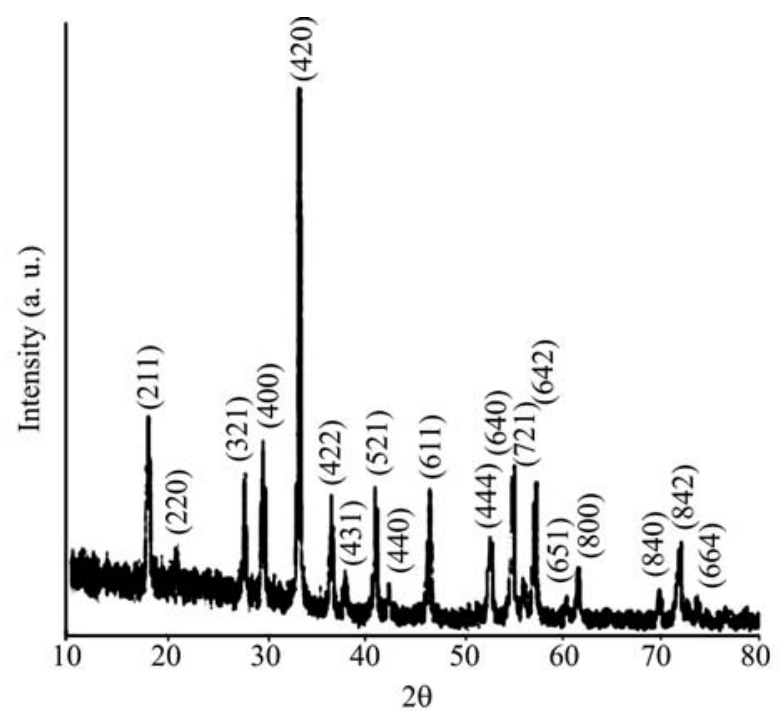

Fig. 2. XRD pattern of Er doped YAG ceramic sample synthesized by the sol-gel method at $1000^{\circ} \mathrm{C}$ (Graskite experience) [8].

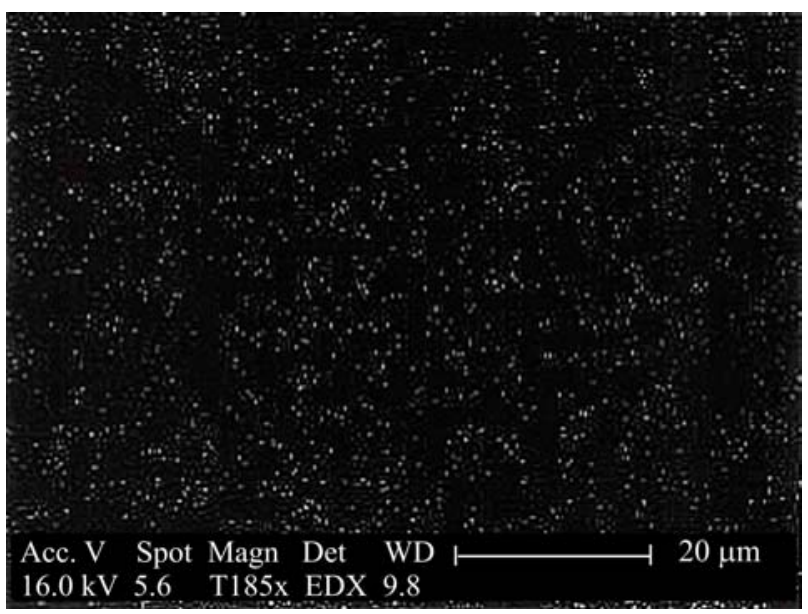

Fig. 3. Distribution of Nd in the YAG structure.

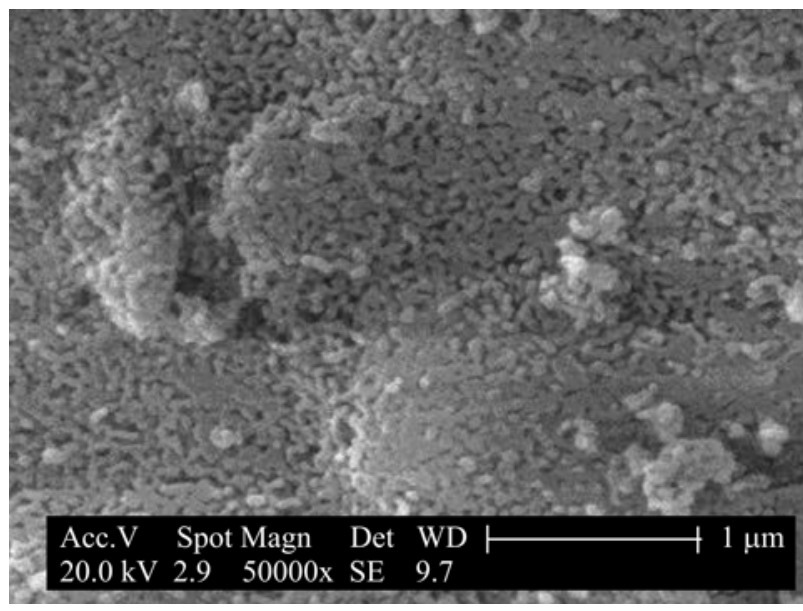

Fig. 4. SEM micrograph of the powder (prepared by the sol-gel method) heated at $900{ }^{\circ} \mathrm{C}$ for $2 \mathrm{hr}$.

\section{Conclusions}

$\mathrm{Nd}$ :YAG powder with 4 at $\% \mathrm{Nd}$ concentration was synthesized by the sol-gel method. The XRD analysis of prepared powder showed that the YAG single phase is resulted by heat treatment at $900{ }^{\circ} \mathrm{C}$ for $2 \mathrm{hr}$. Also by sol-gel method, homogeneous distribution of $\mathrm{Nd}$ over the YAG phase area was obtained. The agglomeration of the powder particles after heating at 900 for $2 \mathrm{hr}$ was observed.

\section{References}

1. V. Luperi, N. Pavel and T. Taira, $1064 \mathrm{~nm}$ laser emission of highly doped $\mathrm{Nd}$ :yttrium aluminum garnet under $885 \mathrm{~nm}$ diode laser pumping // Appl. Phys. Lett. 80, N 23, p.4309-4311 (2002). 
2. J. Lu, T. Murai, K. Takaichi, et al., $72 \mathrm{w}$ $\mathrm{Nd}: \mathrm{Y}_{3} \mathrm{Al}_{5} \mathrm{O}_{12}$ ceramic laser // Appl. Phys. Lett. 78, N 23 (2001).

3. J. Lu, M. Prabhu, J. Song, et al., Optical properties and highly efficient laser oscillation of Nd:YAG ceramics // Appl. Phys. B 71, p. 469-473 (2000).

4. J. Lu, J. Song, M. Prabhu, et al., High power Nd: $\mathrm{Y}_{3} \mathrm{Al}_{5} \mathrm{O}_{12}$ ceramic laser // Jpn J. Appl. phys. 39, p. L1048-L1050 (2000).

5. Ken-ichi Ueda and Jianren Lu, Characterization of transparent lanthanides doped $\mathrm{Y}_{3} \mathrm{Al}_{5} \mathrm{O}_{12}$ and $\mathrm{Y}_{2} \mathrm{O}_{3}$ ceramics, and their laser osillation // Laser Physics 11, p. 1053-1057 (2001).
6. E. Akin, H. Der and A.C. Tas, Chemical preparation of YIG and YAG powders by selfpropagating combustion synthesis // III Ceramics congress, Istanbul, Turkey, Proceedings Book 2, p. 440- 450, October 22-25 (1996).

7. Byung-Joo Chung, Joon-Young Park and Soo-Man Sim, Synthesis of yttrium aluminum garnet powder by a citrate gel method // Journal of Ceramic Processing Research 4, N 3, p. 145-150 (2003).

8. E. Garskite, D. Jasaitis and A. Kareiva, Sol-gel preparation and electrical behavior of Ln:YAG $(\mathrm{Ln}=\mathrm{Ce}, \mathrm{Nd}, \mathrm{Ho}, \mathrm{Er}) / /$ J. Serb. Chem. Soc. 68 (89), p. 677-684 (2003). 